by Richard A. Glen ${ }^{1,2}$, C.D. Quinn ${ }^{l}$ and David R. Cooke ${ }^{3}$

\title{
The Macquarie Arc, Lachlan Orogen, New South Wales: its evolution, tectonic setting and mineral deposits
}

\author{
${ }^{1}$ Geological Survey of New South Wales, Department of Trade and Investment, Regional Infrastructure and Services, P.O. Box 344, Hunter \\ Region Mail Centre, NSW 2310, Australia.E-mail: dick.glen@industry.nsw.gov.au; cameron.quinn@industry.nsw.gov.au \\ ${ }^{2}$ GEMOC ARC National Key Centre, School of Earth and Planetary Sciences, Macquarie University, Sydney, NSW 2109, Australia. \\ ${ }^{3}$ CODES, ARC Centre of Excellence, University of Tasmania, GPO Box 252-79, Hobart, Tasmania 7001, Australia. E-mail: d.cooke@utas.edu.au
}

The Lachlan Orogen of New South Wales, Victoria and eastern Tasmania is the best understood element of the eastern Australian Tasmanides. The Tasmanides encompass continental growth in a Neoproterozoic passive margin setting and a Paleozoic-Mesozoic active margin in east Gondwana, bounded to the east by the Pacific Ocean. In the Ordovician, the supra-subduction zone element in the Lachlan Orogen is the Macquarie Arc. This comprises one minor and three major belts of mafic to intermediate volcanic and volcaniclastic rocks, limestones and intrusions that, with two hiatuses in magmatism, span the Ordovician and extend into the Early Silurian. The three major belts in central New South Wales are separated by Silurian-Devonian rift basins and are therefore, inferred to have been rifted apart during crustal extension. Chemical and isotopic data suggest the Macquarie Arc is intraoceanic, developed on primitive oceanic crust. Despite this, key features such as its longevity, stacked magmatic phases, little deformation and flanking coeval craton-derived turbidites and black shales with no provenance mixing indicate differences from modern intraoceanic arcs. Paleogeographic setting and magmatic evolution of the Macquarie Arc provided perfect conditions for mainly porphyry-related, rich $\mathrm{Au}$-Cu deposits, in the Ordovician, and especially in the Early Silurian after amalgamation of the arc with its flanking terranes.

\section{The Tasmanides and internal subdivisions}

The eastern third of Australia includes five orogenic belts plus a Permian-Triassic basin system that form the eastern Australian Tasmanides (Figure 1). The Delamerian Orogen occupies the southwestern part, the Lachlan Orogen is central and the northeastern part is the New England Orogen. The Thomson Orogen lies N of the Lachlan Orogen almost completely obscured by Mesozoic and Cenozoic cover. The Mossman Orogen occupies the far northeastern part in north Queensland (Figure 1).

The boundary between the Delamerian Orogen and Lachlan Orogen is contentious, even in western Victoria where their outcrops are closest together. Early workers (e.g., Glen, 1992; Wilson et al., 1992) placed the boundary at the Avoca Fault, between the Stawell and Bendigo structural zones (Figure 1) since, on a regional scale it truncates aeromagnetic marker units assigned to the Delamerian Orogen in the west. The Moyston Fault between the Stawell and Glenelg zones has been favoured also (e.g., Cayley and Taylor, 1997, 2001). Early deep seismic reflection data suggested a transitional zone W of the Moyston Fault (Murphy et al., 2006). New seismic data showing that the W-dipping Avoca Fault soles onto the more important crustal-scale E-dipping Moyston Fault was used by Cayley et al. (2011) to support the latter fault being the boundary. This interpretation lies at slight odds with an interpretation of the orogens based on timespace plots, in which a c. 500 Ma deformation characterises the Delamerian Orogen, but not the Lachlan Orogen. This changeover appeared to coincide with the Moyston Fault until Miller et al. (2005) demonstrated c. 500 Ma deformation in the Stawell Zone.

The boundary between the Lachlan Orogen and the Thomson Orogen is concealed by the Mesozoic cover. It is defined by major changes in regional trends, evident in geophysical datasets, with curvilinear WNW-NE trends in the southern part of the Thomson Orogen oblique to NNW-N trends in the northwestern part of the Lachlan Orogen (e.g., Murray and Kirkegaard, 1978; Wellman 1995; Stevens 1991; Glen et al., 2010; Hegarty, 2010). The WNW-trending boundary corresponds to the Olepoloko Fault (Stevens, 1991); the NE-trending part is the Louth-Eumarra Shear Zone of Glen et al. (1996), probably along its northern margin (Glen et al., 2010). Where imaged by deep seismic reflection profiling, the Oelopoloko Fault corresponds to a steep $\mathrm{N}$-dipping reflector that intersects the Moho and separates thick dense crust to the $\mathrm{N}$ from more normal layered crust (Glen et al., 2007d).

The boundary between the Lachlan Orogen and the New England Orogen is obscured by the Permian-Middle Triassic Gunnedah and Sydney basins (Figure 1). These elongate basins evolved from early Permian rifts or transtensional basins into a foreland basin system yoked to the New England Orogen, which underwent conversion to a fold-thrust belt by progressive westward thrusting and folding. 


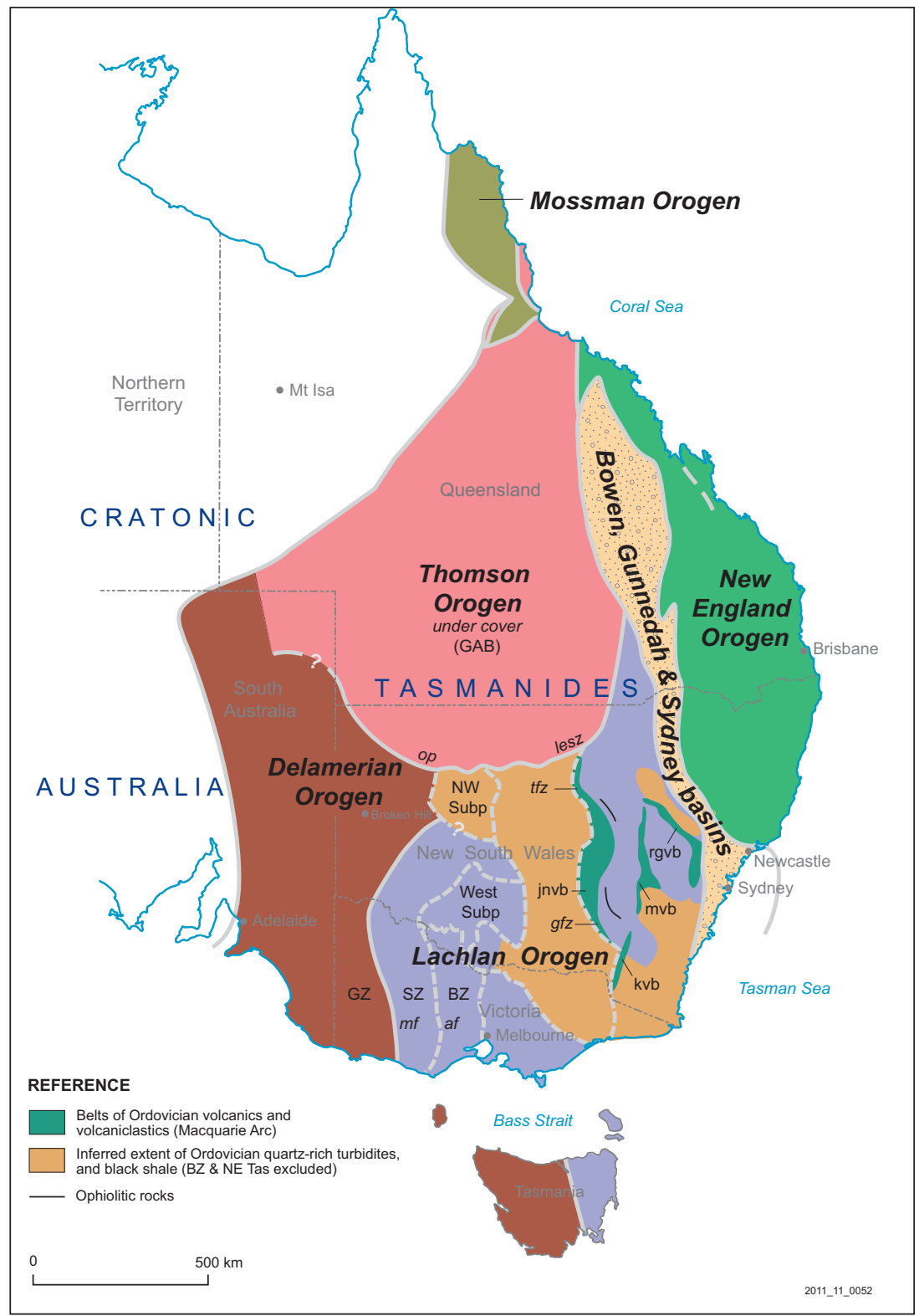

Figure 1 Tasmanides of eastern Australia, showing in green Ordovician belts of Macquarie Arc in the Lachlan Orogen. Abbreviations: $B Z=$ Bendigo Zone; $G A B=$ Great Australian Basin; GZ= Gampians-Stavely Zone, western boundary omitted; SZ = Stawell Zone. Arc belts: jnvb=Junee-Narromine Volcanic Belt; $m v b=$ Molong Volcanic Belt; rgvb=Rockley-Gulgong Volcanic Belt; $k v b=K i a n d r a$ Volcanic Belt. Faults: af =Avoca Fault $; \boldsymbol{m f}=$ Moyston Fault; $g f z=$ Gilmore Fault Zone; les $z=$ Louth Eumarra Shear Zone; op = Olepoloko Fault; tfz=Tullamore Fault Zone.

The northeastern boundary of the Thomson Orogen against the Mossman Orogen (Henderson and Withnall, 2009; North Queensland Orogen of Glen, 2005) has been the subject of discussion (e.g., Day et al., 1978; Murray and Kirkegaard, 1978), but is now generally regarded to lie $\mathrm{N}$ of the Charters Towers Province of the Thomson Orogen.

\section{The Macquarie Arc in the Lachlan Orogen}

The Lachlan Orogen is the central part of the Tasmanides and underlies most of NSW, Victoria and eastern Tasmania. It contains an intraoceanic suprasubduction zone system, the Macquarie Arc, key elements of which are now discussed. This summary draws strongly on results of a joint project undertaken by CODES and the GSNSW, published as Crawford et al. (2007a), and updated by recent detailed mapping in and around parts of the arc by Quinn and coworkers and analysis sampling of detrital zircons undertaken with GEMOC (Macquarie University) and reported in Glen et al. (2011). The work reported in Crawford et al. (2007a) was itself built on joint mapping by GSNSW and Geoscience Australia that produced 1:100 000 scale published maps. This mapping was then used to constrain geochemical sampling, leading to results that updated and built on earlier geochemical work by Pemberton and Offler (1985), Wyborn (1992) and Wyborn and Sun (1993).

Four belts of Ordovician volcanic, sedimentary (volcaniclastic plus limestone) and intrusive rocks in the Lachlan Orogen (Figure 2) have arc-like, calcalkaline geochemistry and trace-element suprasubduction zone signatures. Three occur in central NSW - Junee-Narromine Volcanic Belt in the west; Molong Volcanic Belt in the centre; and the RockleyGulgong Volcanic Belt in the E (Figure 2). The Kiandra Volcanic Belt occurs in the Snowy Mountains, just $\mathrm{N}$ of the Victorian border. Andesitic volcaniclastic rocks interbedded with Ordovician cherts and black shales in the Limestone Creek area of NE Victoria (Figure 2) (Allen, 1988) have also been linked into the Macquarie Arc, but there is no continuity with the southern-most exposure of the Kiandra Volcanics in NSW (Quinn et al., unpublished data).

The three volcanic belts in central NSW have been variously interpreted. Interpretations range from unrelated to subduction, (e.g., the seamount model of Fergusson and Coney (1992) or Wyborn's (1992) model in which magmas were generated by melting of mantle lithosphere that was modified by Cambrian subduction. Subduction models vary from multiple island arcs (Fergusson and Colquhoun, 1996), to a single arc dismembered by strike-slip faulting (Packham, 1987; Fergusson, 2009), or by high-angle rifting during formation of the intervening younger Cowra and Hill End troughs and the Mumbil Shelf (Scheibner, 1989; Glen et al., 1998). Serial restorations based on matching key stratigraphic units across the belts preclude left or rightlateral strike-slip duplication, but support rifting and rigid block rotation (Glen et al., 2007a). Restoration of the arc with an irregular triangular shape (Molong Volcanic Belt and Junee-Narromine Volcanic Belt) projecting eastwards from a $800 \mathrm{~km}$ long baseline represented by the Junee-Narromine Volcanic Belt (inferred to approximate the magmatic core of the arc; Glen et al., 2007c) is also consistent with the matching of key geochemical units across the three belts (Crawford et al., 2007b; Glen et al., 2007b). Further support comes from the interpretation of gravity data and deep seismic reflection profiles that suggest blocks of the Macquarie Arc were 


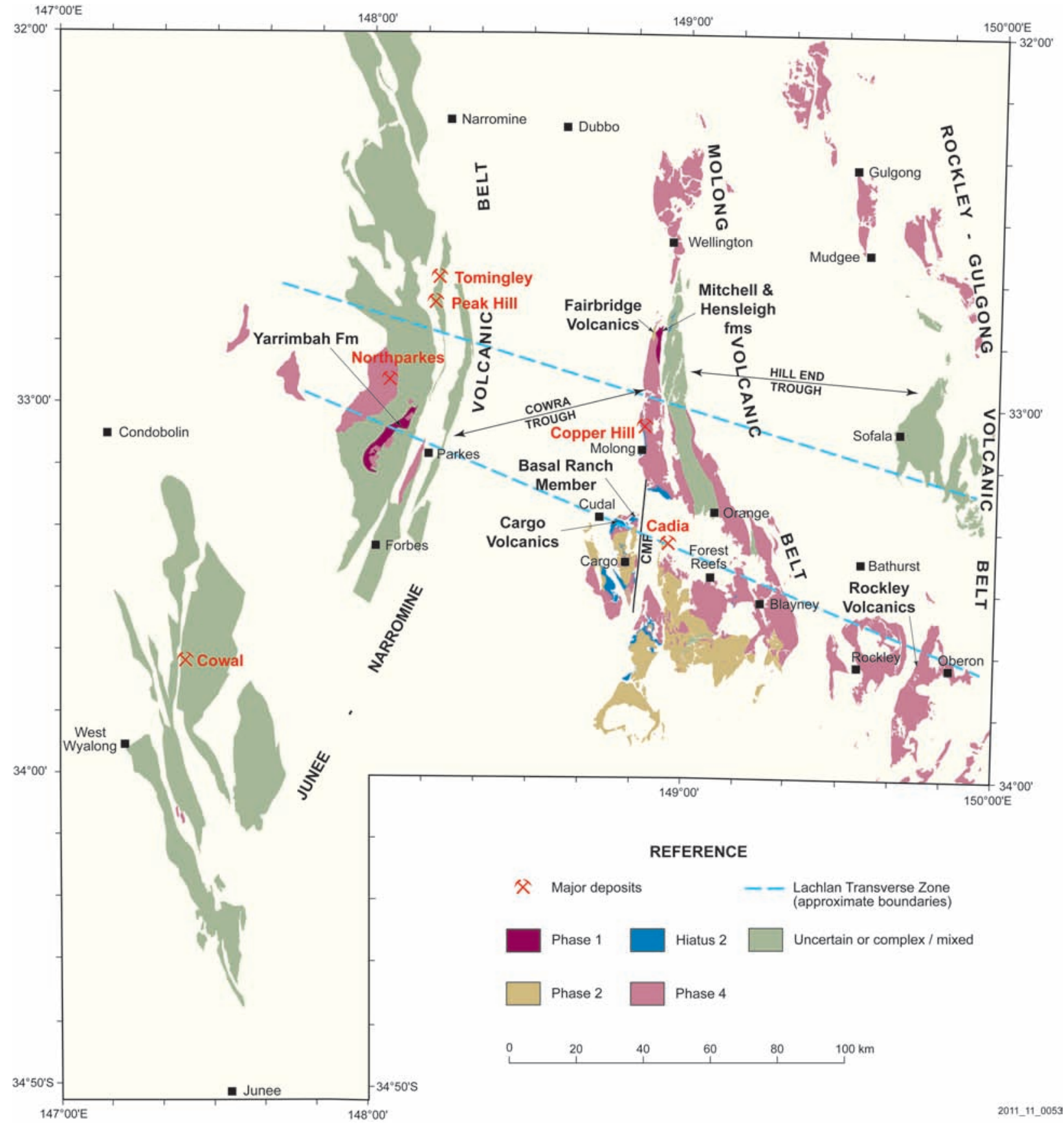

Figure 2 Detail of three belts of Ordovician volcanic and volcaniclastic rocks, limestone and intrusions in central west NSW, showing phases where possible. Separation by Silurian-Middle Devonian rift basins reflects extensional rifting of the arc during these periods. Modified from Percival and Glen (2007).

downthrown along reactivated extensional faults and underlie Silurian-Devonian basins (Glen et al., 2002).

\section{Arc evolution}

Using detailed stratigraphy, Percival and Glen (2007) showed that evolution of the Macquarie Arc in central New South Wales involved three phases of volcanism, common to each of the preserved belts between $>480$ and c. $443 \mathrm{Ma}$ (Figures 2 and 3). Relics of the first Early Ordovician phase occur in the two western belts. The minimum age of Phase 1 magmatism is constrained by overlying Bendigonian graptolites and conodonts (c. 480-476 Ma) and an intruding 481 Ma monzonite (I. Williams, pers. comm; Simpson et al., 2005; Butera et al., 2001). No definitive magmatic zircons have yet been recovered from Phase 1 volcanic rocks, and zircon populations from volcaniclastic rocks show dominantly inherited signatures (Glen et al., 2011). Evolved high-K calc-alkaline to shoshonitic andesitic to basalt-andesitic to basaltic lavas (Glen et al., 2007c) and volcaniclastics developed on emergent islands fringed by shallow-water carbonates and passing up into deepwater siltstones that reflect subsidence.

Phase 1 was followed by a volcanic hiatus of c. 8 Myr, c.474466 Ma (late Bendigonian-early Chewtonian to early Darriwilian). Towards the end of this hiatus, some Early Ordovician rocks were 
uplifted, eroded, and redeposited into sediments associated with Phase 2 arc-wide magmatism. The best example is the clasts of Early Ordovician limestone in the lower Phase 2 volcanics in the northern Molong Volcanic Belt (Percival and Glen, 2007).

Phase 2 magmatism lasted from c. 466-455 Ma (DariwillianEastonian), when it was overlain by an Eastonian 1-3 (455-450 Ma) carbonate platform that marks the second hiatus in arc evolution. Onset of Phase 2 magmatism is not well-defined, and is largely based on ages of allochthonous limestone bodies (Percival and Glen, 2007). Magmatic zircons from two volcaniclastic units provide mean ages of volcanism of 464-463 Ma, which are generally DariwillianGisbornian (Glen et al., 2011). Volcanism during this second magmatic phase was largely submarine. However, in the northern Molong Volcanic Belt, locally emergent volcanic centres were flanked by shallow-water carbonate deposition rapidly passing offshore into deepwater environments marked by mass-flow and turbidite deposits (Simpson et al., 2005, 2007). Intrusive rocks of Phase 2 include 466 and 465 Ma monzodiorites and granodiorites in the Junee-Narromine Volcanic Belt.

Rocks with MORB-like geochemistry attributable to an ophiolite (sensu lato), occur between the Junee-Narromine and Molong volcanic belts (Ashley et al., 1979; Lyons and Percival, 2002) (Figure 2), where they are represented by the Coolac Serpentinite and redeposited fragments in the Silurian Jindalee Group near Cootamundra and Tumut (Quinn et al., unpublished data). Chert fragments yield conodonts from latest Middle Dariwillian (Da4) -earliest Late Ordovician (Gisbornian1, Gi1) - and may be restricted to Gi1. This age is slightly earlier than, or coincident with the onset of Phase 2 arc magmatism (Quinn and Glen, 2009; Quinn and Percival, 2010; Quinn et al., unpublished data).

Crawford et al. (2007b) recorded a stratigraphically upwards shift in geochemistry during Phase 2, from relatively primitive to medium$\mathrm{K}$ calc alkaline to high- $\mathrm{K}$ and shoshonitic compositions.

A carbonate platform overlies Phase 2 rocks in the JuneeNarromine Volcanic Belt and western parts of the Molong Volcanic Belt, and marks the second (c. 455-450 Ma) hiatus in arc magmatism (Figure 3). During hiatus 2, (deepwater) volcanic rocks were uplifted, eroded and overlain by a stable carbonate platform that led to deposition of >360 m of limestone (Percival and Glen, 2007). Dating of magmatic zircons at the base of the hiatus suggests input not only from underlying Phase 2 volcanics, but also from Cambrian primitive mafic melts (Simpson et al., 2007; Glen et al., 2011).

Phase 3 of the arc is represented by the Copper Hill Suite of dacitic and diorite intrusives. At Copper Hill itself, Phase 3 dacite was emplaced during the second arc hiatus, with the best radiometric age being $450 \mathrm{Ma}$ (D. Wyborn, Geoscience Australia OZCHRON database). Crawford et al. (2007b) suggested that the transient Copper Hill Suite marked a brief reversion to medium K-magmatic compositions that interrupted the increasingly shoshonitic trend from underlying to overlying lavas. Crawford et al. (2007b) drew attention to a spread of ages of phase 3 magmatic zircons; Glen et al. (2011) wondered whether some of these reflected older arc magmatism, a concept first suggested by Crawford et al. (2007b).

Phase 4 of arc magmatism (Crawford et al., 2007a) comprises widespread extrusive Late Ordovician (Bolindian, c. 449-443 Ma) lavas and associated sedimentary rocks that postdate the carbonate platform of hiatus 2 as well as richly-mineralised c. 440-437 Ma monzonitic to monzodioritic intrusions coeval with Llandovery sedimentation. Emplacement of these porphyries postdates deformation of Late Ordovician volcaniclastic units and is inferred to postdate the c. $443 \mathrm{Ma}$ first stage of amalgamation of the arc with flanking sedimentary terranes (Glen et al., 2007b).

The onset of Phase 4 volcanism is dated by graptolites as early Bolindian (Percival and Glen, 2007), and occurred after an inferred rifting event marked by sudden depocentre deepening at the end of hiatus 2. This deepening is reflected in collapse of the carbonate platform, carving of submarine valleys, formation of mass flow bodies with clasts of underlying limestone, and deposition of deepwater graptolitic turbidites. Percival and Glen (2007) suggested that the onset of Phase 4 volcanism was diachronous (younging from $\mathrm{W}$ to E). Lava from the Rockley-Gulgong Volcanic Belt contains a zircon magmatic age of c. $454 \mathrm{Ma}$, just below the cessation of the carbonate platform deposition of hiatus 2 in the western Macquarie Arc.

This model of rift-generated uplift and subsidence in hiatus 2 to early Phase 4 replaces the model of Glen et al. (1998), wherein these features were attributed to the attempted subduction of a buoyant seamount.

Phase 4 intrusives are dated at c. 440-437 Ma (Glen et al., 2011) (Figure 3). According to Crawford et al. (2007b), Phase 4 magmatism was almost all shoshonitic, being dominated by more evolved compositions than the shoshonites erupted late in Phase 2. Crawford et al. (2007b) suggested that the more evolved trachyandesitic and trachytic lavas reflected the passing of these magmas through a thicker crust, thereby allowing more time for cooling and fractionation than experienced by phases 1 and 2 lavas.

The Bushman and Nash Hill Volcanics in the Junee-Narromine Volcanic Belt, and the Fifield Alaskan-type zoned complexes intrude Ordovician turbidites $\mathrm{W}$ of that belt. They are regarded as Llandovery, postdating the main development of the Macquarie Arc, and potentially overlapping with Phase 4 intrusives (Crawford et al., 2007b).

\section{Geochemical constraints on the Macquarie Arc}

The lack of continental detritus (Glen et al., 1998; Crawford et al., 2007b; Meffre et al., 2007), the primitive Pb isotopes (Carr et al., 1995; Forster et al., 2011) and the positive whole rock $\varepsilon N d$ of lavas and intrusive rocks (Wyborn and Sun, 1993; Crawford et al., 2007b) are all consistent with formation of the Macquarie Arc as an intraoceanic arc built on primitive oceanic crust. Detrital zircon data from volcaniclastic rocks suggests input from the older Gondwana margin in Phase 1, but only to minor extent in phases 2 and 4 . A key point is the similarity of ages of detrital zircons in Phase 1 volcaniclastics to those in sandstones in the flanking turbidites, suggesting an original position relatively close to the Gondwana margin (Glen et al., 2011).

\section{Deformation}

All volcanic belts are cut by faults ranging from early SilurianCarboniferous. Internal fault deformation and cleavage strain vary from intense to mild. The Junee-Narromine Volcanic Belt and the Molong Volcanic Belt are separated from Silurian-Devonian rocks by thrust faults. The Junee-Narromine Volcanic Belt is sigmoidal, reflecting control by the NNW-trending transpressional Gilmore Fault Zone in the $\mathrm{W}$ and unnamed blind fault in the NE. The west-dipping Gilmore Fault Zone separates the western Junee-Narromine Volcanic 
Belt from coeval Ordovician turbidites to the west, with considerable underthrusting of the volcanics inferred from deep seismic reflection profiling (Glen et al., 2002). It passes northwards, via short unnamed buried faults into the blind Tullamore Fault Zone (Glen et al., 2002).

Despite this deformation, arc rocks are commonly characterised by low to moderate dips and thus low total strain, although localised high-strain zones occur. For example, the Junee-Narromine Volcanic Belt contains an eastern high-strain zone (c. $10 \mathrm{~km}$ wide), marked by subvertical white mica (sub or low grade greenschist) cleavage(s) and internal thrusts. The southern Molong Volcanic Belt contains meridional thrusts that die out approaching a corridor of WNWtrending faults near Cadia mine, that are part of the complex 'arcnormal' Lachlan Transverse Zone of Glen and Walshe (1999) - a low-strain zone marked by the preservation of late-stage porphyries that formed at depths of 2-4 km. Magnetic fabrics also show the Lachlan Transverse Zone to be a low-strain zone (Verard and Glen, 2008). A similar low-strain region, with little post-Ordovician uplift occurs around the Northparkes Mine in the northern Junee-Narromine Volcanic Belt.

\section{Mineral deposits}

The Macquarie Arc hosts porphyry $\mathrm{Cu}-\mathrm{Au}$, epithermal, and structurally-controlled Au-Cu deposits. It is the world's second major alkalic porphyry province, largely because of the Au-rich porphyry deposits associated with alkalic intrusions in the Cadia district in the Molong Volcanic Belt (Cooke et al., 2004, 2007). The combined resources from Cadia make it the sixth largest Au-rich porphyry system on Earth (Cooke et al., 2005), with Ridgeway and Cadia East (underground) among the world's highest grade porphyry Au resources. Mines (Figure 2) include those of the Cadia Valley, those in the Northparkes area ( $n$ in Figure 3 ) and the Cowal mine. Significant resources also occur at Copper Hill (Figure 2), at Tomingley and at the high-sulfidation epithermal deposit at Peak Hill Mine (Figure 2).

The metallogeny of the Macquarie Arc is dominated by alkalic and calc-alkalic porphyry $\mathrm{Au}-\mathrm{Cu}$, skarn, high sulfidation $\mathrm{Au}-(\mathrm{Cu})$, and carbonate base metal epithermal Au deposits The array of deposit types is consistent with subduction-related metallogenic belts in Cenozoic island arcs (e.g., PNG, Indonesia, Philippines). The richest mineralisation is linked to oxidised, small volume, evolved shoshonitic magmatic systems in which $\mathrm{Au}$, chalcophile metals, $\mathrm{Cl}$, and importantly, $\mathrm{H}_{2} \mathrm{O}$, are strongly concentrated relative to precursor mafic and intermediate magmas (Blevin, 2002; Holliday et al., 2002; Lickfold et al., 2007; Cooke et al., 2007). The most obvious marker for such potentially mineralised magmas is their association with large volumes of broadly comagmatic shoshonitic lavas.

Glen et al. (2007c) divided porphyries into four age groups, all of which may be mineralised. Porphyry groups 1-3 are 'pre-accretionary'. They formed during critical events in the evolution of the arc related to interruptions and resumptions of arc activity: group 1 at the end of Phase 1, group 2 at the beginning of Phase 2 and group 3 (Copper Hill suite) during the Late Ordovician hiatus in volcanism. Group 4 porphyries, in contrast, were emplaced between c. 440-437 Ma, in the Llandovery and are 'syn-accretionary'.

Group 4 porphyries are the most highly mineralised. They include the porphyry $\mathrm{Cu}-\mathrm{Au}$ deposits of the Northparkes area in the JuneeNarromine Volcanic Belt, and those in the Cadia Valley area in the southern part of the Molong Volcanic Belt. In both areas, mineralisation is centred in and around quartz monzonite porphyries.
These composite intrusive complexes comprise pipes, dykes and stocks. Hydrothermal alteration in and around the intrusions produced a complex sequence of alteration assemblages, ranging from potassic, calc-potassic, sodic, propylitic and late-stage, typically faultand fracture-controlled phyllic assemblages. Hematite dusting is a common alteration product. Several of the deposits have bornite-rich cores that grade outwards through chalcopyrite-dominant domains to an outer pyritic halo. Gold is well correlated with bornite in most deposits.

Group 4 porphyries were emplaced into folded and tilted volcaniclastic and volcanic rocks that were deformed in the first phase of arc deformation (Benambran Orogeny phase 1, c. $443 \mathrm{Ma}$ ). At Cadia, porphyry emplacement was synchronous with Llandovery rift basins during an extension or relaxation event. These basins were deformed in the late Llandovery $(435-430 \mathrm{Ma})$, in the second phase of the Benambran Orogeny. The WNW-trending Lachlan Transverse Zone (Figure 2) is a major arc-normal corridor and structural direction that favoured emplacement of many porphyries, commonly, but not exclusively shoshonitic. Other WNW-trending faults occur at Tomingley (Alkane Exploration data) and near Cowal Mine, which occurs near the intersection of a N-trending, high-strain corridor.

\section{Plate tectonic setting and key issues}

Glen et al. (2009, 2011) indicated several key features highlighting differences between the Macquarie Arc and 'standard' accreted intraoceanic island arcs. These complicate understanding of the tectonic setting and paleogeography of this part of the Ordovician east Gondwana margin. These are now briefly discussed, based on published work. Undoubtedly new mapping will help fill in the holes in existing data and allow the consideration of new tectonic models to explain the enigmatic Macquarie Arc.

\section{Stacking of arc phases}

The long duration of the Macquarie Arc, c. 37 Myr of volcanism, separated by two hiatuses, plus up to $6 \mathrm{Myr}$ of late intrusive activity contrast with most modern intraoceanic arcs. The vertical stacking of the arc phases requires consistent tracking of the subduction zone with no significant change in dip or direction after each hiatus. Older phases could represent relics of systems that have undergone intraarc rifting and which formed basement for younger arc phases, although in this case, geochemistry is relatively constant throughout. Rifted extinct arcs have not as yet been found.

\section{Relation to flanking sedimentary rocks}

The Macquarie Arc is flanked to the $\mathrm{E}$ and $\mathrm{W}$ by Early-Middle Ordovician turbidites containing two extensive chert horizons (Figure 2). Except in the NW, these turbidites are overlain by Late Ordovician black shales. Sandstones in the turbidite package are craton-derived (up to $90 \%$ quartz, 5\% detrital plagioclase and mica.). Although Powell (1983) suggested that detrital feldspar and mica in Ordovician sedimentary rock were derived from the arc, this has been replaced by consensus that they were derived from plutonic/metamorphic sources. The absence of provenance mixing between turbidite and arc packages (Glen and Wyborn, 1997; Colquhoun et al., 1999; Meffre et al., 2007) is a key feature in 

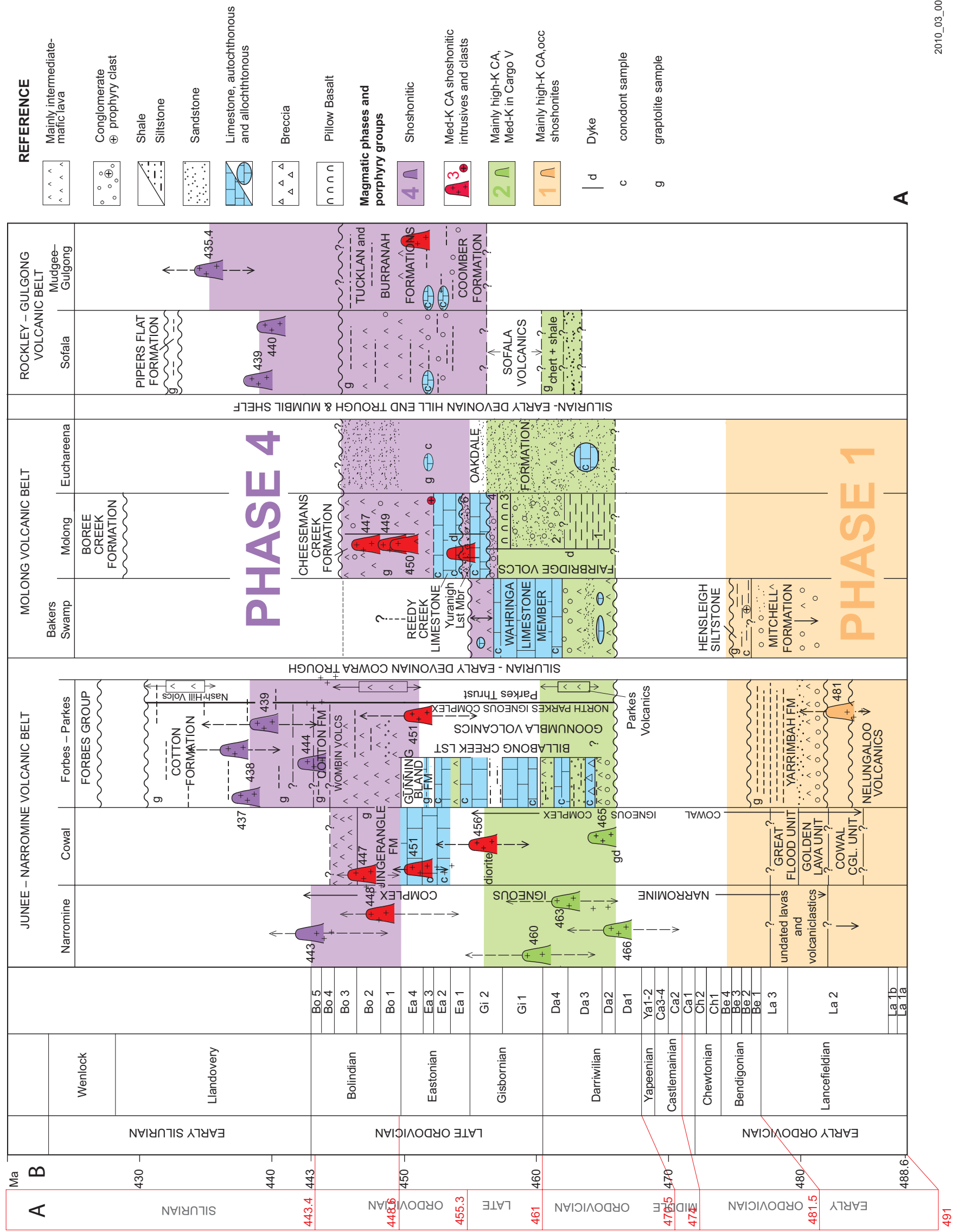


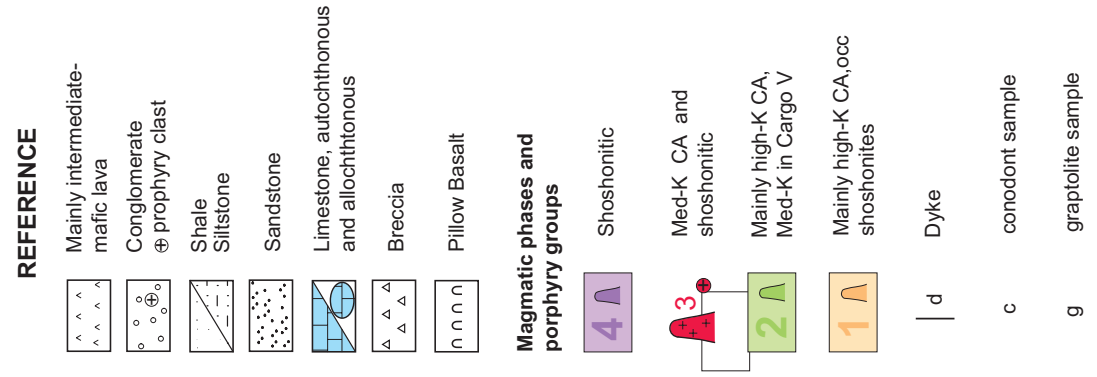


erecting paleogeographic models. As a result, the Lachlan Orogen lacks any forearc basin that can be related to the arc by provenance.

West of the arc, the arc-turbidite contact has been seismically imaged as the Gilmore Fault Zone (Glen et al., 2002). Its extension to the $\mathrm{N}$ comprises short unnamed buried faults that pass northwards into the blind Tullamore Fault System (Glen et al., 2007e). East of the arc there is no clearly defined fault zone and earlier workers suggested concordant or conformable contacts for the Kiandra Volcanic Belt (Owen and Wyborn, 1979) and for the northern RockyGulgong Volcanic Belt (Colquhoun et al., 1999). In the southern Molong Volcanic Belt, suggestions of a $35 \mathrm{~km}$ long regional folded latitudinal fault between volcaniclastic arc rocks in the $\mathrm{N}$ and quartzrich turbidites in the S (Glen, 1998) were based on the absence of provenance-mixing coupled with changes in regional trends (Glen and Wyborn, 1997) and seismic refraction studies (Glen et al., 2002). The progressive realisation that the Early and Middle Ordovician turbidites overlain by Late Ordovician black shales E of the arc are similar to those to the $\mathrm{W}$ of the arc led to the suggestion of duplication of the backarc package. By 2009, detailed biostratigraphic work showed that the Early and Middle Ordovician rocks E and W of the arc are identical (Glen et al., 2009), although the Hermidale Terrane, NW of the arc, lacked Late Ordovician black shales that typified the Albury-Bega Terrane E and W of the arc farther S.

Modifications to this strike-slip model are necessary as detailed remapping around the Kiandra Volcanic belt has shown that the contact between arc volcanics and turbidites is locally concordant, yet disturbed by major soft-sediment deformation, with limited provenance mixing (Quinn and Glen, 2009; Quinn et al., unpublished data; modifying Owen and Wyborn, 1979). These new data suggest an alternative model in which the sedimentary terranes $\mathrm{E}$ and $\mathrm{W}$ of the Macquarie Arc had rifted apart (perhaps obliquely) during Phase 2 of the arc. This rifting was synchronous with earliest Gisbornian abyssal cherts associated with the ophiolite between the eastern and western belts (Quinn and Glen, 2009; Quinn and Percival, 2010; Quinn et al., unpublished data).

\section{Which plate was the Macquarie Arc on?}

In the absence of either forearc basins or subduction complexes, problems arise when trying to deduce which plate hosted the Macquarie Arc and the vector of any related subduction zone. Location on the Gondwana plate above a W(continent)-dipping subduction zone is inferred from the coincidence of changes in arc evolution (e.g. hiatuses) with changes in sedimentation patterns in flanking sediments (Glen, 2005; Glen et al., 2007d, 2009; Quinn and Glen, 2009; Quinn and Percival, 2010; Quinn et al., unpublished data). How long W-dipping subduction persisted into the Late Ordovician is a matter for discussion. Crawford et al. (2007c) and Squire and Crawford (2007) used a Fiji-type model to query whether the shoshonitic Late Ordovician Phase 4 of the arc was subduction-related or represented a change to rifting. Meffre et al. (2007) invoked a possible short period of E-dipping subduction to account for formation of the Copper Hill suite of intrusions.

Uplift, collapse and rifting preceding Phase 2 and Phase 4 magmatism have been referred to above. Linkages between flanking sediments and the Macquarie Arc show that late Middle Ordovician lithological changes immediately preceding Phase 2 arc magmatism were coeval with ophiolite development in a supra-subduction zone rift or marginal basin (Quinn and Percival, 2010; Quinn et al., unpublished data; after Lyons and Percival, 2002).

\section{Acknowledgements}

Thanks to Lawrie Hutton and Ross Cayley for thoughtful reviews. We thank Cheryl Hormann and Phil Carter for cartography. Dick Glen and Cameron Quinn publish with permission of the Acting Director, Geological Survey of New South Wales, NSW Office of Resources and Energy.

\section{References}

Allen, R.L., 1988, Limestone Creek Graben, in Douglas, J.G. and Ferguson, J.A. (eds), Geology of Victoria: Geological Society of Australia Inc, Victorian division, Melbourne, p. 92.

Ashley, P.M., Brown, P.F., Franklin, B. J., Ray, A.S. and Scheibner, E., 1979, Field and geochemical characteristics of the Coolac Ophiolite suite and its possible origin in a marginal sea: Australian Journal of Earth Sciences, v. 26 , pp. $45-60$.

Blevin, P.L., 2002, The petrographic and compositional character of variably $\mathrm{K}$-enriched magmatic suites associated with Ordovician porphyry $\mathrm{Cu}$ $\mathrm{Au}$ mineralisation in the Lachlan Fold Belt, Australia: Mineralium Deposita, v. 37, pp. 87-99.

Butera, K.M., Williams, I.S., Blevin, P.L. and Simpson, C.J., 2001, Zircon $\mathrm{U}-\mathrm{Pb}$ dating of early Palaeozoic monzonitic intrusives from the Goonumbla area, New South Wales: Australian Journal of Earth Sciences, v. 48 , pp. $457-464$.

Carr, G., Dean, J.A., Suppel, D.W. and Heithersay, P.S., 1995, Precise lead isotope fingerprinting of hydrothermal activity associated with Ordovician to Carboniferous metallogenic events in the Lachlan Fold Belt of New South Wales: Economic Geology, v. 90, pp. 1467-1505.

Cayley, R.A. and Taylor, D.H., 1997, Grampians special map area geological report: Geological Survey of Victoria, Report 107, $150 \mathrm{pp}$.

Cayley R.A. and Taylor D.H., 2001, Ararat 1:100 000 geological map report. Geological Survey of Victoria, Report 115.

Cayley, R.A., Korsch, R.J., Moore, D.H., Costelloe, R.D., Nakamura, A., Willman, C.E., Rawling, T.J., Morand, V.J., Skladzien, P.B. and O'Shea, P.J., 2011, Crustal architecture of central Victoria: results from the 2006 deep crustal reflection seismic survey: Australian Journal of Earth Sciences, v. 58, pp. 113-156.

Colquhoun, G.P., Fergusson, C.L. and Tye, S.C., 1999, Provenance of early Palaeozoic sandstones, southeastern Australia, Part 2: cratonic to arc switching: Sedimentary Geology, v. 125, pp. 153-163.

Cooke, D.R., Wilson, A.J. and Lickford, V., 2004, Alkalic porphyry Au-Cu deposits of the Macquarie Arc, NSW, in Bierlein, F.P. and Hough, M.A. (eds), Tectonics to Mineral Discovery - deconstructing the Lachlan Orogen: Geological Society of Australia, Abstracts, v. 74, pp. 49-50.

Cooke, D.R., Hollings, P. and Walshe, J.L., 2005, Giant porphyry deposits characteristics, distribution and tectonic controls: Economic Geology, v. 100 , pp. $801-818$.

Cooke, D.R., Wilson, A.J., House, M.J., Wolfe, R.C., Walshe, J.L., Lickfold, V. and Crawford, A.J., 2007, Alkalic porphyry $\mathrm{Au}-\mathrm{Cu}$ and associated mineral deposits of the Ordovician to Early Silurian Macquarie Arc, New South Wales: Australian Journal of Earth Sciences, v. 54, pp. 445-463.

Crawford, A.J., Glen, R.A., Cooke, D.R. and Percival, I.G., 2007a, Geological evolution and metallogenesis of the Ordovician Macquarie Arc, Lachlan Orogen, New South Wales: Australian Journal of Earth Sciences, v. 54, pp. $137-479$.

Crawford, A.J., Meffre, S., Squire, R.J., Barron, L.M. and Falloon, T., 2007b, Middle and Late Ordovician magmatic evolution of the Macquarie Arc: Lachlan Orogen, New South Wales: Australian Journal of Earth Sciences, v. 53, pp. 181-214.

Crawford, A.J., Cooke, D.R. and Fanning, C.M., 2007c, Geochemistry and 
age of magmatic rocks in the unexposed Narromine, Cowal and Fairholme Igneous Complexes in the Ordovician Macquarie Arc, New South Wales: Australian Journal of Earth Sciences, v. 53, pp. 243-271.

Day, R., Murray, C.G. and Whittaker, W.G., 1978, The eastern part of the Tasman Orogenic Zone: Tectonophysics, v. 48, pp. 327-364.

Fergusson, C.L., 2009, Tectonic evolution of the Ordovician Macquarie Arc, central New South Wales: arguments for subduction polarity and anticlockwise rotation: Australian Journal of Earth Sciences, v. 56, pp. 179-193.

Fergusson, C.L. and Colquhoun, G.P., 1996, Early Palaeozoic turbidite fan and volcaniclastic apron, Mudgee district, northeastern Lachlan Fold Belt, New South Wales: Australian Journal of Earth Sciences, v. 43, pp. 497507.

Fergusson, C.L. and Coney, P.J., 1992, Implications of a Bengal Fan-type deposit in the Paleozoic Lachlan fold belt of southeastern Australia: Geology, v. 20, pp. 1047-1049.

Forster, D.B., Carr, G.R. and Downes, P.M., 2011, Lead isotope systematics of ore systematics of ore systems of the Macquarie Arc-implications for arc substrate: Gondwana Research, v. 19, pp. 686-705.

Glen, R.A., 1992, Thrust, extensional and strike-slip tectonics in an evolving Palaeozoic orogen - a structural synthesis of the Lachlan Orogen of southeastern Australia: Tectonophysics, v. 214, pp. 341-380.

Glen, R.A., 1998, Structural Geology, in Pogson, D.J. and Watkins, J.J. (compilers), Bathurst 1:250 000 Geological Sheet SI/55-8. Explanatory Notes: Geological Survey of New South Wales, Sydney, pp. 287-310.

Glen, R.A., 2005, The Tasmanides of eastern Australia, in Vaughan, A.P.M., Leat, P.T. and Pankhurst, R.J. (eds), Terrane Processes at the Margins of Gondwana: Geological Society of London, Special Publication, v. 246, pp. 23-96.

Glen, R.A. and Walshe, J.L., 1999, Cross structures in the Lachlan Orogen: The Lachlan Transverse Zone example: Australian Journal of Earth Sciences, v. 46, p 641-658.

Glen, R.A. and Wyborn, D., 1997, Inferred thrust imbrication, deformation gradients and the Lachlan Transverse Zone in the eastern belt of the Lachlan Orogen, New South Wales: Australian Journal of Earth Sciences, v. 44 , pp. $49-68$

Glen, R.A., Clare A. and Spencer, R., 1996, Extrapolating the Cobar Basin model to the regional scale: Devonian basin-formation and inversion in western New South Wales: The Australasian Institute of Mining and Metallurgy, Spectrum Series, v. 3/96, pp. 43-83.

Glen, R.A., Walshe, J.L., Barron, L.M. and Watkins, J.J., 1998, Ordovician convergent-margin volcanism and tectonism in the Lachlan sector of east Gondwana: Geology, v. 26, pp. 751-754.

Glen, R.A., Korsch, R.J., Direen, N.G., Jones, L.E.A., Johnstone, D.W., Lawrie, J.C., Finlayson, D.M. and Shaw, R.D., 2002, Crustal structure of the Ordovician Macquarie Arc, Eastern Lachlan Orogen, based on seismicreflection profiling: Australian Journal of Earth Sciences, v. 49, pp. 323348.

Glen, R.A., Meffre, S. and Scott, R.J., 2007a, Benambran Orogeny in the Eastern Lachlan Orogen, Australia: Australian Journal of Earth Sciences, v. 54, pp. 385-415.

Glen, R.A., Crawford, A.J., Percival, I.G. and Barron, L.M., 2007b, Early Ordovician development of the Macquarie Arc, Lachlan Orogen, New South Wales: Australian Journal of Earth Sciences, v. 54, pp. 167-179.

Glen, R.A., Crawford, A.J., and Cooke, D.R., 2007c, Tectonic setting of porphyry $\mathrm{Cu}-\mathrm{Au}$ mineralisation in the Ordovician - Early Silurian Macquarie Arc, Eastern Lachlan Orogen, New South Wales: Australian Journal of Earth Sciences, v. 54, pp. 465-479.

Glen, R.A., Poudjom-djomani, Y., Korsch, R.J., Costello, R.D. and Dick, S., 2007d, Thomson-Lachlan seismic project - results and implications, in Lewis, P.C. (ed), Mines and Wines 2007: Australian Institute of Geoscientists, Bulletin, v. 46, pp. 73-78.

Glen, R.A., Spencer, R., Willmore, A., David, R. and Scott, E.J., 2007e, JuneeNarromine volcanic belt, Macquarie Arc. Lalchan Orogen, New South Wales: Components and Structure: Australian Journal of Earth Sciences, v. 54 , pp. $215-241$
Glen, R.A., Percival, I.G. and Quinn, C.D., 2009, Ordovician continental margin terranes in the Lachlan Orogen, Australia: implications for tectonics in an accretionary orogen along the east Gondwana margin: Tectonics, v. 28, TC6012, doi:10.1029/2009TC002446.

Glen, R.A., Saeed, A., Hegarty, R., Percival, I.G., Bodorkos, S. and Griffin, W.L., 2010, Preliminary zircon data and tectonic framework for the Thomson Orogen, northwestern NSW: Geological Survey of New South Wales, Report GS 2010/0379.

Glen, R.A., Saeed, A., Quinn, C.D. and Griffin, W.L., 2011, U-Pb and Hf isotope data from zircons in the Macquarie Arc, Lachlan Orogen: Implications for arc evolution and Ordovician palaeogeography along part of the east Gondwana margin: Gondwana Research, v. 19, pp. 670685, doi:10.1016/j.gr.2010.11.011.

Hegarty, R.A., 2010, Preliminary geophysical-geological interpretation map of the Thomson Orogen in Thomson Orogen: release of preliminary and provisional information, June 2010 (Digital Dataset): Geological Survey of New South Wales, Maitland.

Henderson, R.A. and Withnall, I.W., 2009, Phanerozoic geology of north Queensland: Australian Institute of Geoscientists, Bulletin, v. 49, pp. 135-136.

Holliday, J.R., Wilson, A.J., Blevin, P.L., Tedder, I.J., Dunham, P.D. and Pfitzner, M. 2002, Porphyry gold-copper mineralisation in the Cadia district, eastern Lachlan Fold Belt, New South Wales, and its relationship to shoshonitic magmatism: Mineralium Deposita, v. 37, pp. 100-116.

Lickfold, V., Crawford, A.J. and Cooke, D.R., 2007, Magmatism associated with the Northparkes $\mathrm{Cu}-\mathrm{Au}$ mineralisation: Australian Journal of Earth Sciences, v. 54, pp. 417-444.

Lyons, P. and Percival, I.G., 2002, Middle to Late Ordovician age for the Jindalee Group of the Lachlan Fold belt, New South Wales: conodont evidence and some tectonic implications: Australian Journal of Earth Sciences, v. 49, pp. 801-808.

Meffre, S., Scott, R.J., Glen, R. and Squire, R., 2007, Re-evaluation of contact relationships between Ordovician volcanic belts and the quartz-rich turbidites of the Lachlan Orogen: Australian Journal of Earth Sciences, v. 54 , pp. $363-383$.

Miller, J.M., Phillips, D., Wilson, C.L.J. and Dugdale, L.J., 2005, Evolution of a reworked orogenic zone: the boundary between the Delamerian and Lachlan fold belts, southeastern Australia: Australian Journal of Earth Sciences, v. 52, pp. 921-940.

Murphy, F.C., Rawling, T.J., Wilson, C.J.L., Dugdale, L.J. and. Miller, J.McL., 2006, 3D structural modelling and implications for targeting gold mineralisation in western Victoria: Australian Journal of Earth Sciences, v. 53 , pp. $875-889$

Murray, C.G. and Kirkegaard, A.G., 1978, The Thomson Orogen of the Tasman Orogenic Zone: Tectonophysics, v. 48, pp. 299-325.

Owen, M. and Wyborn, D., 1979, Geology and geochemistry of the Tantangara and Brindabella 1:100 000 Sheet areas, New South Wales and Australian Capital Territory: Bureau of Mineral Resources, Bulletin, v. 204, pp. 152.

Packham, G.H., 1987, The eastern Lachlan fold belt of southeast Australia: a possible Late Ordovician to Early Devonian sinistral strike slip regime, in Leitch, E.C. and Scheibner, E. (eds), Terrane Accretion and Orogenic Belts: Geodynamic Series, v.19, pp. 67-82.

Pemberton, J.W. and Offler, R., 1985, Significance of clinopyroxene compositions from the Cudgegong Volcanics and Toolamanang Volcanics; Cudgegong-Mudgee district, NSW, Australia: Mineralogical Magazine, v. 49 , pp. $591-599$.

Percival, I.G. and Glen, R.A., 2007, Ordovician to Earliest Silurian History of the Macquarie Arc, Lachlan Orogen, New South Wales: Australian Journal of Earth Sciences, v. 54, pp. 143-165.

Powell, C.M., 1983, Tectonic relationships between the Late Ordovician and Late Silurian palaeogeographies of southeastern Australia: Journal of the Geological Society of Australia, v. 30, pp. 353-373.

Quinn C.D. and Glen R.A., 2009, A new supra-subduction zone rift model for the eastern Lachlan Orogen, south-eastern Australia: implications of intimately-related siliciclastic turbidite and volcanic packages, in Glen 
R.A. and Martin C. (eds), International Conference on Island Arc Continent Collisions: the Macquarie Arc Conference, April 2009: Geological Society of Australia, Abstracts, v. 92, p.113.

Quinn, C.D. and Percival, I.G., 2010, Correlating the Lachlan and New England Orogens, eastern Australia, in Buckmann, S., and Blevin, P.L. (eds), Proceedings of the New England Orogen Conference: University of New England, Armidale, pp. 276-280.

Sadler, P.M., Cooper, R.A. and Melchin, M., 2009, High-resolution, early Paleozoic (Ordovician-Silurian) time scales: Geological Society of America, Bulletin, v. 121, pp. 887-906.

Scheibner, E., 1989, The tectonics of New South Wales in the second decade of application of the plate tectonic paradigm: Royal Society of New South Wales, Journal and Proceedings, v. 122, pp. 35-74.

Simpson, C.J., Cas, R.A.F. and Arundell, M., 2005, Volcanic evolution of a long-lived Ordovician island arc province in the Parkes region of the Lachlan Fold Belt, southeastern Australia: Australian Journal of Earth Sciences, v. 52, pp. 863-886.

Simpson, C.J., Crawford, A.J. and Scott, R.J., 2007, The volcanology, geochemistry and tectonic implications of the Cargo Volcanics in the Cargo-Walli region, central NSW Cargo Block, Macquarie Arc, NSW: Australian Journal of Earth Sciences, v. 54, pp. 315-352.

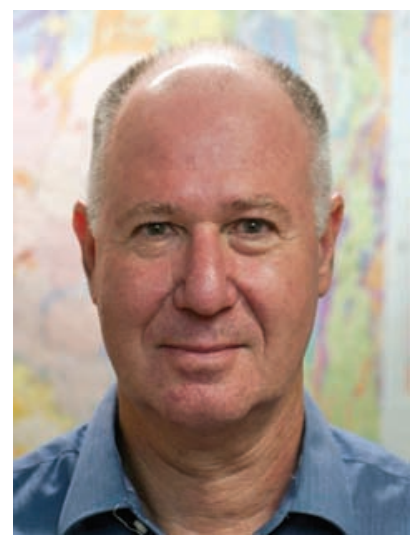

Dick Glen is a research scientist in the Geological Survey of New South Wales, part of the NSW Department of Trade and Investment. He works on processes involved in, and crustal architecture and possible mineralising systems that formed during, the geological development of the Tasmanides of eastern Australia, within the context of interactions between the eastern Gondwana and the paleo-Pacific plate.

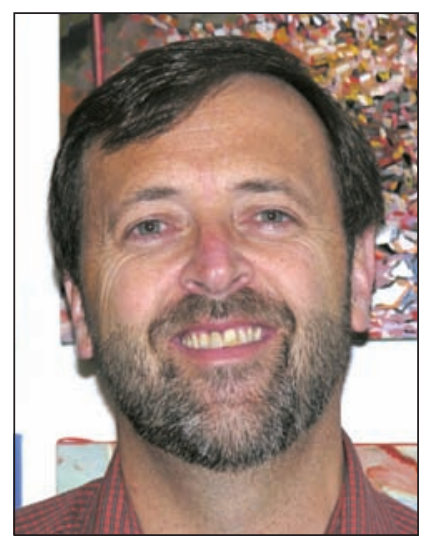

David Cooke is a Professor at the University of Tasmania, where he leads the Ore Deposit Formation research program at CODES, the Australian Research Council's Centre of Excellence in Ore Deposits. Over the past two decades, he and his students and postdoctoral research fellows have researched the ore deposits of the Macquarie Arc. He currently leads two major research projects into the geochemical footprints of porphyry and epithermal deposits from the circum-Pacific region.
Stevens, B.P.J., 1991, Northwestern New South Wales and its relationship to the Lachlan Fold Belt: Geological Society of Australia, Abstracts, v. 29, p. 50 .

Verard, C. and Glen, R.A., 2008, Magnetic fabrics of Palaeozoic rocks across the Lachlan Transverse Zone from eastern New South Wales: Australian Journal of Earth Sciences, v. 55, pp. 1037-1048.

Webby, B.D., Cooper, R.A., Bergstrom, S.M. and Paris, F., 2004, Stratigraphic framework and time slices, in Webby, B.D., Paris, F., Droser, M.L. and Percival, I.G. (eds), The great Ordovician biodiversification event: Columbia University Press, New York, pp. 41-47.

Wellman, P., 1995, Tasman Orogenic System: a model for its subdivision and growth history based on gravity and magnetic anomalies: Economic Geology, v. 90, pp. 1430-1442.

Wilson, C.J.L., Will, T. M., Cayley, R.A. and Chen, S., 1992, Geological framework and tectonic evolution in western Victoria: Tectonophysics, v. 214, pp. 93-127.

Wyborn, D., 1992, The tectonic significance of Ordovician magmatism in the eastern Lachlan Fold Belt: Tectonophysics, v. 214, pp. 287-303.

Wyborn ,D. and Sun S.-S., 1993, Nd-isotopic 'fingerprinting' of $\mathrm{Cu} / \mathrm{Au}$ mineralisation in the Lachlan Fold Belt: AGSO Research Newsletter, v. 19 , pp. 13-14.

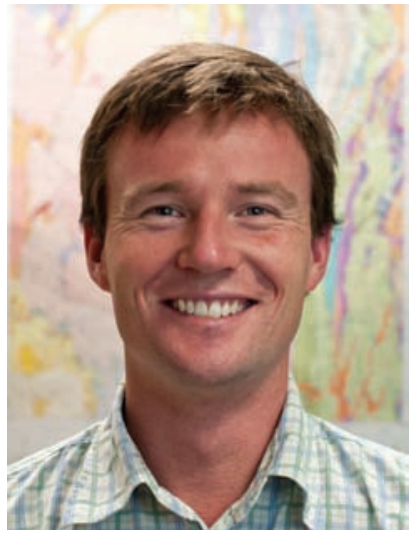

Cameron Quinn is a research scientist with the Geological Survey of NSW, NSW Department of Trade and Investment. His main interests include the geology and mineralisation of the Macquarie Arc and Lachlan Orogen, comparison with other orogenic belts and the tectonic reconstruction of Gondwana. Recently, his work has focused on the unusual contact relationships between arc and passive margin turbidites in the eastern Lachlan Orogen. 